Article

\title{
The Use of PPGIS: Towards Reaching a Meaningful Public Participation in Spatial Planning
}

\author{
Edyta Bąkowska-Waldmann *(D) and Tomasz Kaczmarek \\ Faculty of Human Geography and Planning, Adam Mickiewicz University, Krygowskiego 10, 61-680 Poznań, \\ Poland; tomasz.kaczmarek@amu.edu.pl \\ * Correspondence: edyta.bakowska@amu.edu.pl
}

check for

updates

Citation: Bakkowska-Waldmann, E.; Kaczmarek, T. The Use of PPGIS:

Towards Reaching a Meaningful

Public Participation in Spatial

Planning. ISPRS Int. J. Geo-Inf. 2021,

10, 581. https://doi.org/10.3390/

ijgi10090581

Academic Editors: Jakub Lysek,

Enzo Falco, Jiří Pánek and

Wolfgang Kainz

Received: 1 July 2021

Accepted: 26 August 2021

Published: 28 August 2021

Publisher's Note: MDPI stays neutral with regard to jurisdictional claims in published maps and institutional affiliations.

Copyright: (c) 2021 by the authors. Licensee MDPI, Basel, Switzerland. This article is an open access article distributed under the terms and conditions of the Creative Commons Attribution (CC BY) license (https:/ / creativecommons.org/licenses/by/ $4.0 /)$.

\begin{abstract}
Together with technological innovations and the development of a digital society, PPGIS approaches have been rapidly growing popular in the last years, in Poland's local administration. Local governments take significant interest in online tools; however the principles of public participation, which, in fact, should also be applied to e-consultations, are still missing. One of the assumed roles of PPGIS is to support public participation-not just in terms of the number of stakeholders, but especially in terms of the impact on decision making. The present paper discusses the results of investigations into two decision-making processes, regarding local spatial planning in the Poznań agglomeration, Poland, conducted in 2015-2021. Its aim is to verify the hypothesis that the use of PPGIS facilitates more meaningful involvement of citizens in spatial planning. As a result of the case study analysis, in-depth interviews with local authorities and officials, and analysis of the planning documents and the role of PPGIS in public participation in decision making, was investigated. It was shown that in both processes there was no direct participation of society in decision making. However, the use of PPGIS, according to local authorities, had implications in the context of the wider process of local governance.
\end{abstract}

Keywords: public participation in GIS; spatial planning; decision-making; geoparticipation; governance

\section{Introduction}

The models of public management in democratic countries emphasize an increasingly important role of society in decision-making processes [1-3]. The participation of citizens in these processes is defined as public participation, the role of which is closely related to the evolution of public management models and changes in society [4]. According to Banyan [5], public participation can be defined as the use of diverse formal and informal instruments, allowing citizens to present their values, expectations, and preferences to the authorities. This approach is mainly focused on the methodological and formal view of participation; however, public participation should be considered as citizens' contributions to decision-making processes, based on communication and dialogue [6].

It is claimed that the standards and levels of public participation in spatial planning are insufficient, ineffective, and scarce [7]. Among the characteristics of top-down public participation processes are the following: low attendance, inadequate representation of different (for example, age) groups of citizens, and ineffective ways of communicating and presenting consulted issues. In addition, the involvement of citizens too late in the process (this happens when decisions have been already made) limits public participation to only a reaction to these decisions, which denotes that they are left with no actual impact on the decisions [8]. As Kingston et al. [9] state, public meetings, which are one of the most common methods of public participation, are organized in a confrontative atmosphere, dominated by those who are determined to raise their voice to express their opinions and interests-not always supported by the opinions and interests of the majority. As a 
consequence, stakeholders are being placed in a confrontation that raises tensions and limits citizens' trust in authorities [10]. A common limitation of this method is the dependence on the place and time of the meeting.

Nowadays, new multi-stakeholder frameworks and models of territorial governance emerge. Such concepts as new public governance, good governance, new municipalism, and new spatial planning are based on the idea of deliberative democracy [11-14]. They emphasize that public participation is not only listening to public preferences, but it is rather the effect of the exchange of opinions and arguments of those involved in the process. This form of public participation, through the involvement of different stakeholders, provides a stronger legitimacy of the decisions taken. It represents the transition from representative to deliberative democracy, often influenced by the consolidation of social movements (mainly in the form of so-called urban movements) and grassroots initiatives in spatial planning [15].

The problem raised in this paper treats spatial planning as a decision-making processan indispensable element of governance at the local level, constituting a sequence of milestones based on the collection of information and its processing, in order to make final, long-term decisions [16]. These processes can be supported by PPGIS, defined as a set of methods and tools based on geographic information systems for engaging the public in decision-making processes in spatial planning [17-20]. PPGIS approaches are innovative in public participation processes in territorial governance (especially in spatial planning); however, preceding research does not bring the full answer, regarding their role in participatory decision making. Besides the growing number of PPGIS implementations in local governments [20-22], their role in decision-making processes and the empowerment of citizens still seems unanswered. According to Falco [23], the potential of digital solutions and especially the use of internet methods of public participation support the development of higher (than with traditional, commonly used methods) levels of public participation on Arnstein's ladder of public participation. Potentially, open access to the process, unlimited by the place and time of the meeting, creates an opportunity for the participation of the broader public and increases the interest in local matters. As a consequence, it is assumed that decision-making processes will be more open and transparent $[19,24,25]$.

\subsection{Aim of the Research}

The aim of the research presented in this paper is to analyze the role of PPGIS in decision making, and its influence on the elimination of standard public participation procedure limitations, as in the example of the geo-questionnaire-a PPGIS tool in the form of an online questionnaire with an interactive map. The analysis was made on the basis of two case studies of decision-making processes in Poznan agglomeration, Poland, introduced further in the article. The research area was selected due to the cooperation with the local governments of Poznan agglomeration within the "GEOPLAN" project that was conducted at the Adam Mickiewicz University in Poznan. The local governments in this area, including Poznań in particular, in comparison to others in Poland, are considered as precursors of implementing new models for local government units' managementnew public management in the 1990s and participatory governance in the 2000s [26]. As a consequence, local authorities were open to conduct pilot implementations of geoquestionnaires in their units.

Local governments in Poland, called communes (gminy), may take the form of urban communes (cities), urban-rural communes (a city with a group of villages), or rural communes (a group of villages). In Poland, it is the most important structure of decentralized power. The competence of local governments is to meet the primary needs of local communities, providing basic social and technical services, including spatial planning tasks. In the scope of local matters, the local government is complemented by the county selfgovernment (powiat), but without planning competences, and the regional self-government (województwo), which is responsible for matters of a regional range. The area of research, i.e., 
Poznan agglomeration, is made up of the city of Poznań and the surrounding urban-rural and rural communes.

The principal research problem of the paper was whether the use of PPGIS in public participation processes supports citizens' roles in decision making. To resolve this problem, the authors formulated the following three research questions:

- RQ1: What are the local authorities' motivations for applying PPGIS in public consultations?

- RQ2: To what extent are the results of e-consultations using PPGIS tools used in the decision-making process?

- RQ3: Does the use of PPGIS increase the level of public participation in terms of citizens' empowerment?

The article opens with a discussion on the role of public participation in spatial planning. An important element in understanding the Polish specificity is also the presentation of the legal conditions of these processes. The introductory part of the article ends with the presentation of the research methods used to answer the research questions. In the results section, the findings, based on the evaluation of PPGIS implementations in decisionmaking processes, were presented. Despite the legal, institutional, and social conditions that are typical of Poland, the results of the research may be of a more universal nature, as the discussed issues are characteristic to the application of PPGIS.

\subsection{Power Relations in Spatial Planning}

One of the assumed roles of PPGIS is to support public participation-not only in terms of the number of stakeholders, but also, and especially, regarding the level (quality) of participatory decision making [25,27]. It can be understood as the degree of empowerment of residents in local governance policies. Starting from Arnstein [28], many researchers use the ladder metaphor to systematize the forms and level of citizens' involvement in the management processes [29-31]. In Arnstein's ladder, public participation is considered as a spectrum of power-from the manipulation of citizens to social control, thus focusing on the power that residents have in their decision-making processes. Power in the matter of citizenship, as Flyvbjerg [32] notes, according to Habermas's theory of communicative action, is being defined in terms of taking part in public debate. The aim of public participation in spatial planning, especially in the initial stages of the processes, is to reduce possible conflicts. It supports broadening knowledge about the space, creates citizens awareness about spatial and environmental issues, as well as different interests and expectations, and is one of the main spheres of public activity [8,33-35].

A common term in discourse about conflicts of interests in spatial planning is a "game for space" [36]. It is characterized by opposing interests, and reaching a compromise depends primarily on a key actor in the process-administration-which is responsible for the final results of the planning process [37]. In a so-called "game for space", stakeholders have different levels, sources, and characteristics of knowledge about a given topic, and they formulate various expectations [38]. It is a calculation of costs and benefits of different, sometimes contradictory, spatial development scenarios. On the one hand, they can result from the local government's spatial development policy, but, on the other, legislation and imperfection of the law at the national level. The game for space [36] is a manifestation of neoliberal urbanism, where investors possessing financial resources play a key role. At the same time, a local government, which should act in the interests of residents, adopts the position of regulator [15,39]. The emerging complex structures and decision-making systems weaken the role of local communities.

The commonly used methods of public participation seem to be strongly ineffective, limiting the actual participation of citizens who are affected directly by the changes in spatial development. They arouse anger and incomprehension, and increase tensions among the participants of the planning process, bringing them into confrontation $[8,40]$. One of the main pleas against those processes is that they are not commonly accessible to the public; however, more and more scholars question the importance and profits of 
general public participation [41]. It seems that among the aims of public participation in spatial planning, a reduction in conflicts, by diagnosing them at an early stage, is one of the most important steps in the planning practice. It requires not only knowledge and competencies from the administration, regarding the diagnosis of the conditions of the processes, but also tools and methods supporting the effective inclusion of key stakeholders in decision making [42].

\subsection{Assumptions of PPGIS}

The concept of PPGIS was constituted in 1996, during the National Center for Geographic Information and Analysis meetings. The idea behind PPGIS was to shed a new light on the role of GIS in supporting the participation of local communities in spatial planning [19,43-45]. In its early days, PPGIS relied on simple tools, such as paper maps, pens, and stickers, etc. Later, digital mapping with computers (desktop-based) was introduced. The internet (web-based GIS) and applications based on GIS were the next step in the development of PPGIS [27,44,46]. Nowadays, PPGIS methods are part of the so-called geoparticipation, understood as the use of GIS for participatory mapping [47]. It follows the assumption that residents are not only the object of planning processes (as users of planned and developed geographical space), but also the creators of these activities-an entity in the decision-making processes in spatial planning [36,48]. According to Panek et. al. [49], geoparticipation can have the following three dimensions: communication, participation, and transparency, with varying impacts on spatial planning.

According to Ghose [50], the use of PPGIS supports reducing the strength of the power relations in spatial planning, by creating online networks of residents, associations, investors, and city planners. These networks provide opportunities to challenge spatial development problems arising from neo-liberal urban policies, and GIS is an important component of these efforts [51]. Also, as Wójcicki [40] comments, the use of digital methods of public consultations, such as PPGIS, supports the improvement (in the sense of time) of planning processes. They may represent the potential to engage less-active groups, increase social trust, and increase the awareness of the determinants of planning processes. In light of these notions, PPGIS can be viewed as an instrument that changes power relations in the processes of territorial governance. This idea guides the development of one of the most important goals of PPGIS, which is the involvement of citizens in planning processes, leading to their participation in decision making on the issues that will directly affect their lives.

\subsection{Formal and Legal Conditions of Public Participation in Poland}

The legal provisions regarding public participation in spatial planning in Poland result from the act on spatial planning and development of 2003, the act on communes' self-government of 1990, the Constitution of the Republic of Poland, and the civil code. These documents indicate the protection of the legal interest of landowners, thus giving them the opportunity to dispose of their property to the extent that the legal interests of other people will not be limited. However, the understanding of the legal interests and impact of the investment on the other parties is very flexible and not clearly defined. The act on spatial planning and development guarantees public participation in the procedure of developing local spatial development plans and studies of the conditions and directions of spatial development in four forms. Local spatial development plan (local plan) is a document regulating the spatial development of a given area, prepared at the local level. A local spatial development plan must result from precedent regulations, formulated in a study of the conditions and directions of spatial development (spatial study), prepared for the whole commune. Both documents are legally regulated by Polish law. Public participation in these procedures includes the following forms of involvement: submitting proposals to the project, observing the project, participation in the public discussion on the project, and submitting comments to the project. 
The current model of spatial planning in Poland (Figure 1), according to which the processes discussed in the article were implemented, consists of four phases (similar for local plans and spatial studies). The purpose of the first, initial phase is to decide whether to start works on the project and, if this is the case, to adopt a resolution on the preparation of a local plan or spatial study. The goal of the next phase (diagnostic) is to define the conditions and guidelines for the design. It is a phase in which relevant data are collected and processed-submitting proposals to the project also takes place at this stage (1). In the early design phase, the first versions of the project are developed - at this stage, tasks related to the design and verification of scenarios are introduced. This phase ends with the preparation of the first version of the project, which has to be reviewed by external institutions. The final phase, from the point of view of public participation, is the only one in which there is open communication (mutual and two-way) with the stakeholders of the process. Anyone interested might see the project (2), take part in the public discussion (3), and submit comments to the project (4). The consequence of late public involvement is a renewed increase in the intensity of the design works, resulting from the comments of the residents (and other interested actors) on the project viewed by them for the first time. If the scope of the expected changes (and thus the lack of public acceptance for the indicated solutions) is significant, the design team has to return to the project phase and repeat the formal procedures. This can significantly extend the duration of the planning procedure. The reason for such a situation is the lack of communication with the stakeholders of the process at the earlier stages, including their lack of involvement in the diagnosis of the spatial conditions and at the designing stage. However, at the same time, it is not forbidden, and might be implemented as an informal (not regulated at the national level) public participation.

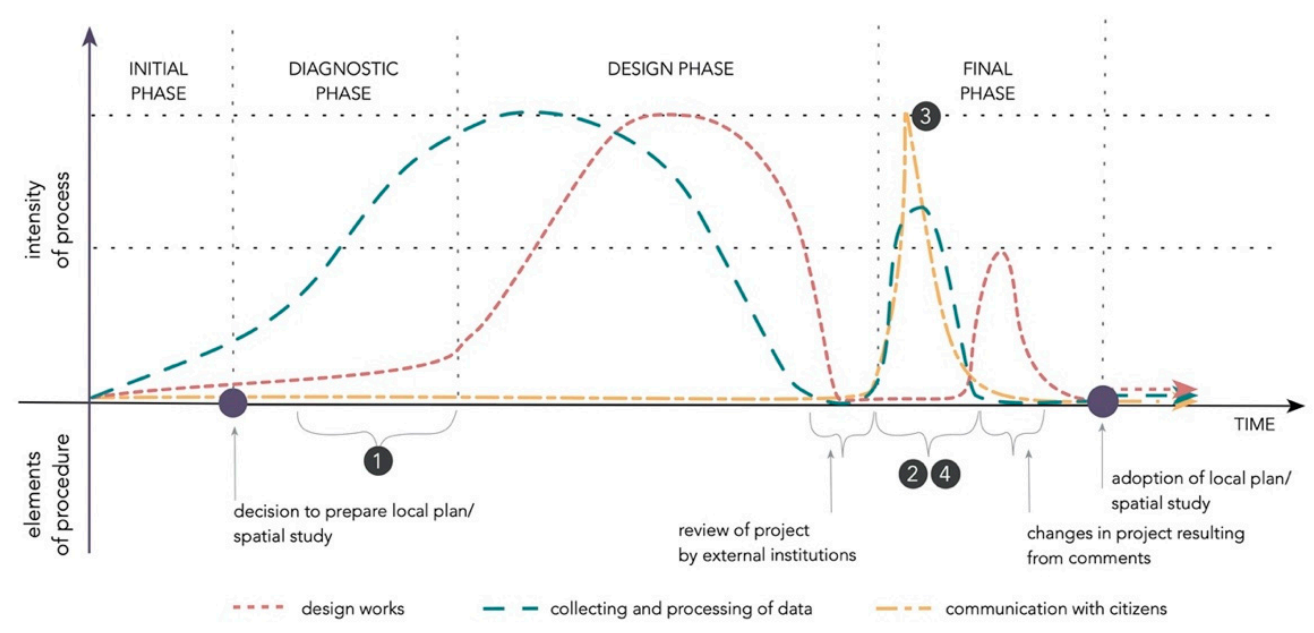

Figure 1. Model of formal spatial planning in Poland. Source: own elaboration based on act on spatial planning and development of March 2003.

Despite the formal provisions of public participation in spatial planning in Poland, the following deficits are indicated in the literature [36,52-57]:

- Low attendance and insufficient representativeness of citizens;

- Low communicativeness (specialized content and language);

- Late participation of residents in the planning process;

- No real influence of residents on decisions;

- Limiting participation to a reaction on the decisions already made;

- Legal obligation to carry out public consultations instead of dialogue and negotiations;

- Bringing stakeholders into confrontation, generating tensions among the participants of the planning process.

As noted by Izdebski et al. [58], the provisions on spatial planning in Poland restrict public participation, assigning it the features of a procedure that is, in principle, to protect 
the legal interest of the resident. Thus, instead of striving to empower society in the planning process, the participation of residents is reduced to the implementation of statutory requirements. According to the national legal regulations and jurisprudence, the protection of property rights is superior to the protection and fulfillment of the needs of other entities, who do not have the right to a given property and who will be affected by the regulations of the local plan or spatial study [37]. The legal provisions concerning public participation in spatial planning do not oblige the authorities to make decisions based on the results of public consultations. As a result, these processes can be recognized as a façade or tokenistic. Balancing the interests of private and public entities is one of the most important issues of law in the field of spatial planning in Poland [52,59].

\section{Materials and Methods}

\subsection{Research Design}

The idea of the research approach was to broaden the number of thoroughly executed examples (case studies) of PPGIS use as a contribution to development of PPGIS theory. With a special focus on the evaluation of the processes concerning the effects on decision making, the paper is a response to the research gap in the area of PPGIS, pointed to by Brown and Kyttä [20,60]. To identify the possibilities and effects of PPGIS use in decision making in spatial planning, the authors decided to conduct a case study analysis [61] including in-depth interviews and analysis of documents to investigate the implementation of public consultation results (Figure 2). The research process was conducted in parallel to the design process - two administrative procedures of decision making. As a consequence of investigating actual planning procedures, the research process took seven years; it started in 2015 and was completed in 2021.

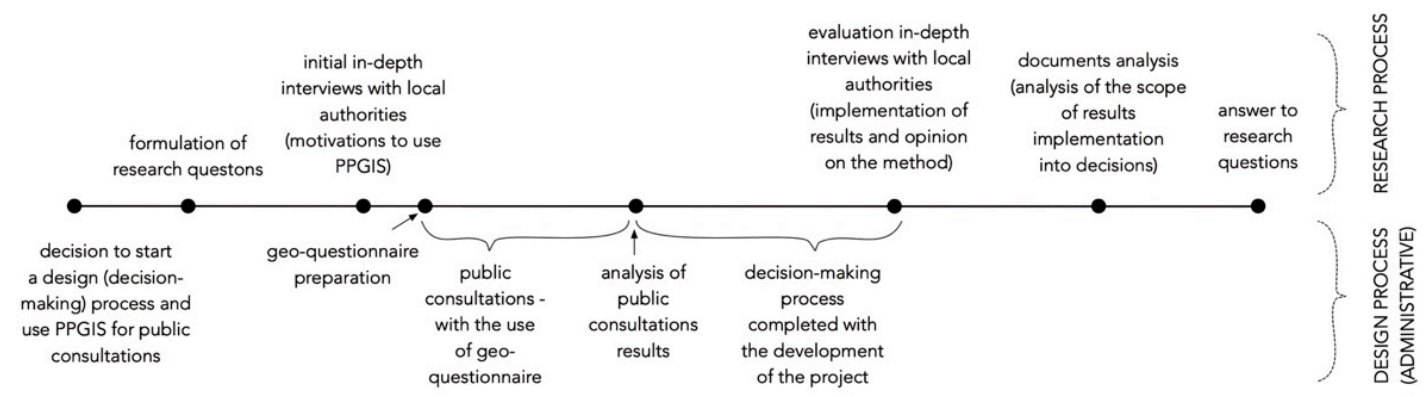

Figure 2. Research process and the administrative design process. Source: own elaboration.

The two analyzed case studies (described in the next section) constituted the decisionmaking processes in which an online PPGIS tool-geo-questionnaire-was implemented. Geo-questionnaire (Figure 3) is the combination of an online questionnaire and interactive map, which makes it possible to answer the questions regarding the points indicated by the respondent on the map. This term refers to the combination of a questionnaire (-questionnaire) and functions enabling the location of elements in space (geo-) [21,62,63]. The tool used in the research results from an R\&D project "GEOPLAN" financed by the Polish National Centre for Research and Development, where the authors were also members of the research team. Geo-questionnaires, key means of public consultations used in the studied processes, were prepared for the investigated processes in a process of cooperation between representatives of local government units, entities responsible for spatial development concepts (external urban planning offices), and members of the "GEOPLAN" research team, who created the software and the methodology of its use. The authors' role was to support the organizers of the process as to the methodological correctness of the questionnaire implementation, as well as the analysis (quantitative and GIS) of the results and the formulation of recommendations. 


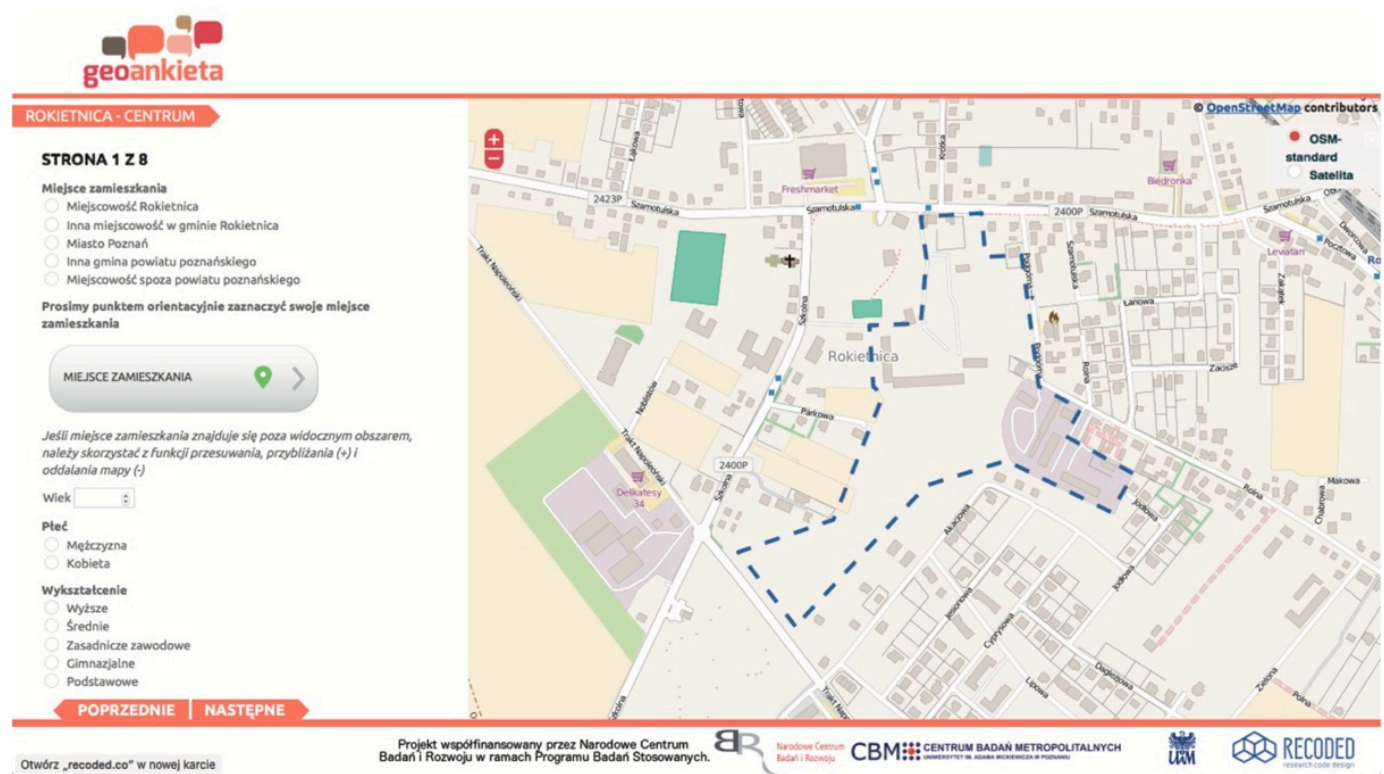

Figure 3. An exemplary page of the geo-questionnaire.

Individual in-depth interviews with local authorities were conducted at two stages of decision-making procedures-at the beginning of the processes (initial) and after decisions (final). They were conducted among representatives of local authorities-mayors and heads of planning departments - two persons interviewed for each of the analyzed cases at the beginning and at the end of the processes. The first turn of interviews made it possible to learn about the motivations and attitudes of the interviewees regarding implementing PPGIS in public consultations. To present the results of the interviews a narrative description was used. The narrative, as one of the key methods of analysis in social sciences, allowed building a cause-and-effect relationship, thus capturing the broader context of the analyzed case studies [32]. Individual in-depth interviews were carried out using a specific scenario. This type of interview made it possible to identify motivations regarding the decisions made, attitudes and represented views, and is a valuable method in the study of leaders and hard-to-reach people, including politicians and officials [64,65]. The conducted interviews were, each time, an hour-long conversation between the respondent (interlocutor) and the researcher (questioner). The interviews were conducted at the interviewee's workplace and recorded. The purpose of the interviews was to learn about the motivations and attitudes of the interviewees towards the use of a PPGIS tool, as well as to evaluate their application in relation to the studied cases.

The aim of the interviews was to present the perspective and position of local authorities and employees responsible for spatial planning in the communes, to explore the impact of the results of public consultations on the decisions taken. According to the Polish spatial planning system, it is the commune head who is responsible for the preparation of the planning documents. Under Polish law, residents, who in theory should be the main subjects of spatial management, do not have sufficient tools to influence decision making, i.e., it is not mandatory to take into account their comments on the project. Interviews with decision makers who played a key role in the decision-making process were one of the bases for achieving the objectives of the study, namely, the impact of PPGIS application on decision making, not only the evaluation of the method itself. Other key participants of the process, i.e., land owners, due to other (financial) motivations, which were contrary to the interests of residents and local government, participated in the process using formal (different than the geo-questionnaire) ways and lobbying. On the other hand, urban planners (representatives of external urban planning offices) were not interested in participating in the research, as it was beyond the scope of the contract with local government units. 
During meetings with the organizers of public consultations that initiated works, each process was characterized by the following features: the identification of the planning situation, timetable, areas of consultations, stakeholders and the scale of their participation. Also, motivations and expectations of the local authorities' representatives (two mayors and two heads of spatial planning departments), which accompanied the decisions to use PPGIS, were investigated via initiating interviews including the following questions:

- How did you intend to use the geo-questionnaire results in your work?

- What impact did you expect on the work of entities responsible for the preparation of the plan?

- What kind of public opinion about the used method did you expect?

- What was the motive for the decision to use the tool?

- Were the potential conflicts in the planning process significant while making a decision to use this method?

The second turn of interviews conducted at the final stage of decision-making processes was focused on the evaluation of the method's use itself and on the use of results in decision-making processes. The interviews were conducted according to the following scenario:

- What were the main dilemmas/problems related to the content of the project?

- Did the geo-questionnaire data help to solve these dilemmas?

- Did the data obtained during the consultations influence the decisions made? (If not, why not?/If so, which data?/If so, which decisions?)

- Was the data collected through the questionnaire useful during the work on the project?

- Which elements of the results were, in your opinion, most useful?

- Did the data help to better understand the needs, perspectives or attitudes of the participants in the consultation?

- Did the data influence your opinion on the content of the project?

- Would it be possible to obtain such data in other ways?

- What were the benefits of using the tool?

- Did the tools generate any additional difficulties/concerns/costs?

- Were the benefits greater than the costs in your opinion?

At the final stage of the research, the authors analyzed the materials connected with the planning procedures, created during the years in which design processes were carried out, and other strategic materials for the development of these areas. This included legal instruments, graphic materials and other documents created during the process by official institutions, private urban planning offices and media. They are presented in more detail in Table 1.

Table 1. Types of materials analyzed in research.

\begin{tabular}{|c|c|c|}
\hline Legal Documents & Graphic Materials & Other Materials \\
\hline $\begin{array}{l}\text { resolutions on the preparation of } \\
\text { local spatial development plans }\end{array}$ & $\begin{array}{l}\text { draft designs provided by } \\
\text { urban planners }\end{array}$ & $\begin{array}{l}\text { protocols from } \\
\text { commune councils' } \\
\text { sessions }\end{array}$ \\
\hline $\begin{array}{l}\text { local spatial development plans } \\
\text { (text and graphic appendix) }\end{array}$ & $\begin{array}{c}\text { official design concepts } \\
\text { presented by local authorities }\end{array}$ & media information \\
\hline
\end{tabular}

These materials were analyzed both in terms of the determinants of the decisions (i.e., resulting from precedent regulations and strategic plans) and the verification of the scope of implementation of the geo-questionnaire results into the final projects. This helped to thoroughly assess the inclusion of the results of public consultations into decisions. The aim of documents analyses was a comparison of the geo-questionnaire results and the final projects. The documents analysis according to Bowen's approach [66] was a way to verify findings from other sources, in this example in-depth interviews with officials. 
The evaluation of PPGIS implementation in relation to the level of public participation was prepared according to the classification adopted by the International Association for Public Participation [67]. It consists of the following five levels of public participation (from the lowest): information, consultation, involvement, cooperation and empowerment. Nyerges et al. [68] determined the activities undertaken by the participating stakeholders and the processes that take place at each level of the classification. At the information level (1), the public listens to the statements of the authorities in one-way communication. At the consultation level (2), government representatives ask the public for input and provide feedback, but do not necessarily act upon it. This level is common in traditional meetings, i.e., public discussions. At the inclusion level (3), groups are engaged in the process by offering recommendations. However, there is no guarantee that the information will translate into final decisions, but it is expected to be considered in the decision-making process. At the cooperation level (4), residents collaborate with government officials or with each other in order to provide even better input and recommendations to design processes, but they are still excluded from making final decisions. On the last level, empowerment (5), decision-making is collaborative and final decisions are made by the citizens involved in the process.

\subsection{Selected Cases}

The research was conducted in the rapidly developing suburban communes of the city of Poznań-Rokietnica and Swarzędz (Tables 2 and 3). The investigated decision-making processes in both cases were connected with legal procedures on preparation of local spatial development plans. However, the implementation of PPGIS into procedures was a non-obligatory (not required by law) element of the processes. In Rokietnica as well as in Swarzędz, geo-questionnaires were used at the initial stage of the procedures. The processes indicated were related to the expected changes in land use of given areas. In both cases the areas for strategic development of communes were of major importance and what was expected were serious conflicts of interest—-between property owners (and potential investors), local authorities and neighborhood residents.

Table 2. Characteristics of the analyzed applications of PPGIS tools.

\begin{tabular}{|c|c|c|c|c|c|c|}
\hline ID & Name & $\begin{array}{l}\text { Area Covered by } \\
\text { Consultations }\end{array}$ & $\begin{array}{l}\text { Duration of } \\
\text { Process }\end{array}$ & $\begin{array}{l}\text { Number of } \\
\text { Respondents }\end{array}$ & $\begin{array}{c}\text { Number of } \\
\text { Residents at Age } \\
\text { of 15-69* }\end{array}$ & Turnout $* *$ \\
\hline CS1 & $\begin{array}{l}\text { New Center of } \\
\text { Rokietnica }\end{array}$ & 16.0 ha & 2015-2021 & $\begin{array}{l}482 \text { (1st stage) and } \\
163 \text { (2nd stage) }\end{array}$ & 11,430 & $\begin{array}{l}4.2 \% \text { (1st stage), } \\
1.4 \% \text { (2nd stage) }\end{array}$ \\
\hline CS2 & $\begin{array}{c}\text { Land-use change of } \\
\text { sports airport area } \\
\text { Poznań-Kobylnica in } \\
\text { Swarzędz }\end{array}$ & 150.0 ha & 2016-ongoing & 933 & 36,263 & $2.5 \%$ \\
\hline
\end{tabular}

* In 2015 for Rokietnica and in 2016 for Swarzedz. ** The turnout was calculated in relation to the number of inhabitants of communes, at the age 15-69 years. Source: own elaboration based on geo-questionnaire results and census data.

Table 3. Current land use of the analyzed areas and applicable legal guidelines.

\begin{tabular}{|c|c|c|}
\hline ID & Input Development State-At the Beginning of the Process & Precedent Regulations in Spatial Study \\
\hline CS1 & $\begin{array}{c}\text { Brownfields after former food cooperative, fallow land, ruined } \\
\text { buildings, wild greenery }\end{array}$ & $\begin{array}{l}\text { Multi-family and single-family housing, } \\
\text { services }\end{array}$ \\
\hline CS2 & Sports airport, headquarter of sport aviation club, wild greenery & Mono-functional land use-airport \\
\hline
\end{tabular}

Source: own elaboration based on communes spatial studies.

The aim of a local spatial development plan in Rokietnica (formally the area was divided into three local spatial development plans; however, they were proceeded at the same time and bordered with each other. In the article, they will be referred to as one plan) was to regulate a land use of brownfields in the very center of the village in order to create the representative commune's center that was missing so far. Formally, 
Rokietnica is a village in a commune with the same name. Owing to its location in the first ring of the Poznan suburban area, it is a typical example of a rapidly developing suburb and should be rather recognized as a small town - the number of residents of the commune in 2019 reached 18,637 (in 1999-7657, and in 2009-11,696). As a result, the regulation of investment pressure in housing is one of the main goals of local development policy. A 16-ha area in the center of Rokietnica is being recognized in the official plans as strategic investment reserve. In the preceding regulations and a spatial study, the target area was specified as a new functional center of the village, with public spaces, public offices, housing, services and new roads. The main challenge of the decision-making process was to reconcile interests of the following main stakeholders: owners of the area (an increase in or maintenance of an investment value), residents in the neighborhood (an increase in or maintenance of the quality of life), and local authorities representing the local community (costs of real estate purchase for public use and possible compensations for the loss of a private value to its owners). Within a geo-questionnaire, respondents were asked inter alia about their preferences on building density and height, a transportation system, the location of a public square. Formally, the implementation of PPGIS in the case of Rokietnica took place twice. Firstly, at the diagnostic stage, i.e., during the collection of proposals regarding the local spatial development plan/when proposals regarding the local spatial development plan were collected. Secondly, at the advanced stage of the works after devising the concept, yet before the review of external opinion bodies.

The second case study - a decision-making process connected with the preparation of the local spatial development plan in Swarzędz - was focused on finding a new land use for the area of a former sports airport. The area under study was a 150.0 ha of greenery located next to the single-family housing residential area. After sports club's decision to relocate its headquarter, the aim of the former owners was to sell the area to a new investor interested in building warehouses (or other forms of economic activity). It required changes in the spatial study and the preparation of a local spatial development plan. However, because of a residential neighborhood and the lack of sufficient transportation infrastructure for that kind of land use, local authorities were sceptic. At the initial phase of the process, local authorities decided to recognize public opinion on the future development of this area. From the beginning, there was a visible conflict of interest between property owners and local authorities. Also, media were engaged. Within a geo-questionnaire, respondents were asked about their preferences to land use and the transportation system. Within this process the geo-questionnaire was used at the pre-planning phase (before the formal preparation of local plans).

The duration of both processes was longer than a standard procedure. The minimal time required to prepare and adopt a local plan is about nine months. If there is a requirement to also make changes in the spatial study, the time doubles. In Rokietnica, a local spatial development plan procedure took six years. In Swarzędz, the plan preparation process started in 2016 and in 2021 the procedure has still not been finished (only the draft project has been presented by local authorities). Different stakeholders' interests in both cases required negotiations, which greatly extended the duration of decision-making processes.

The geo-questionnaire, due to the fact that it was an element of an open and common process of public consultations, was addressed to all entities interested in changes in the spatial development of the areas under consultation. Therefore, statistical methods of selecting the research sample were not applied, so as not to limit the potential stakeholders' role in the spatial planning process. Participants were invited to get involved in public consultations through customary forms of communication between commune offices and residents (including social media, traditional media, local press, and leaflets delivered to residents' mailboxes). As is typical for online public consultation methods, the respondents of geo-questionnaires in both cases were mainly people aged 25-45 with higher education. In the case of the geo-questionnaire for Rokietnica, the participants accounted for $2.9 \%$ of the population, and in the case of Swarzedz they represented 1.3\% of the population. In 
both cases the population is understood as registered citizens of communes aged 15-69. Figures 4 and 5 show the age and gender structures of the respondents in comparison to the age and gender structures of the populations of the communes.

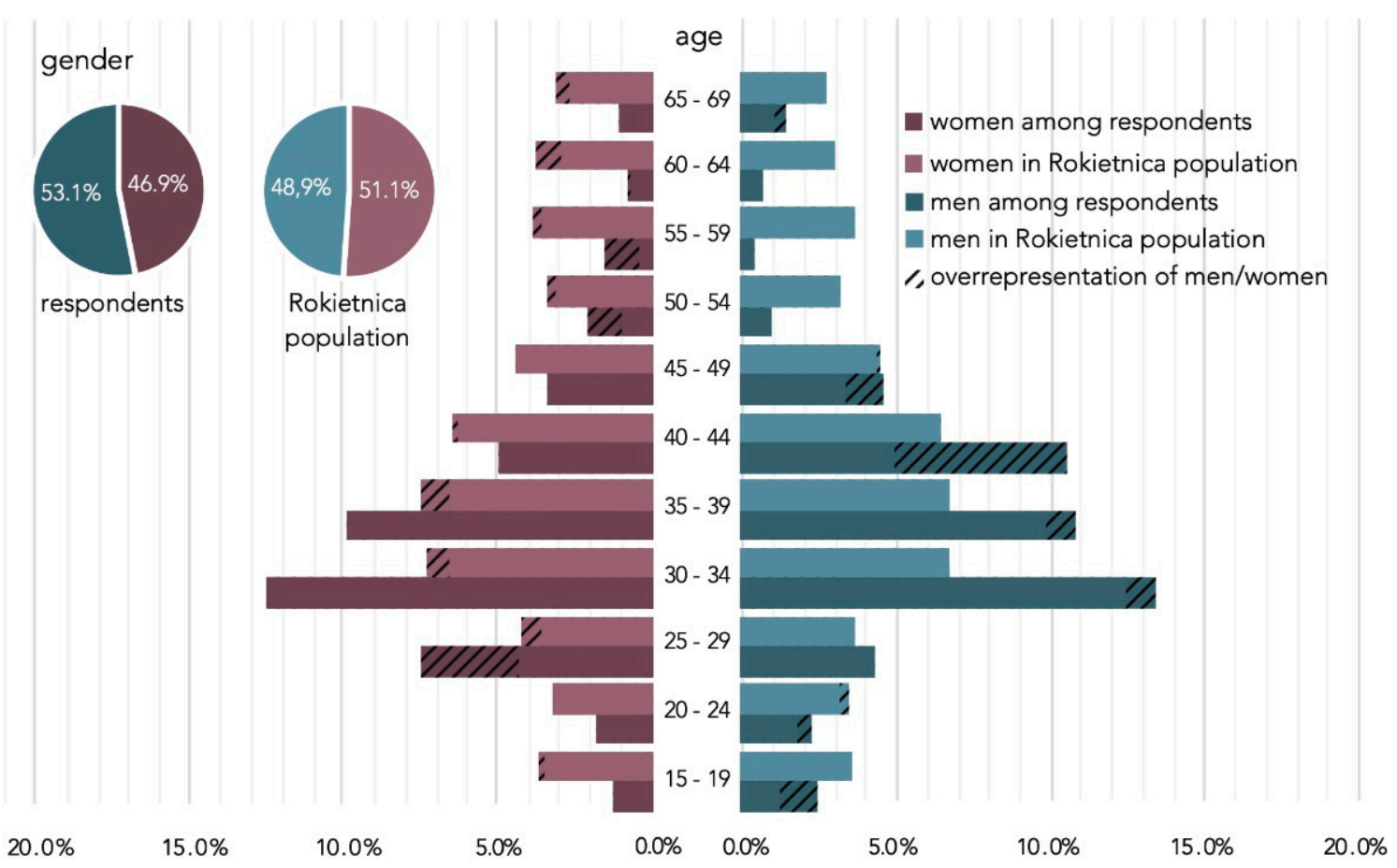

Figure 4. Age and gender structure of respondents in Rokietnica commune. Source: own elaboration based on geoquestionnaire results and statistics Poland data.

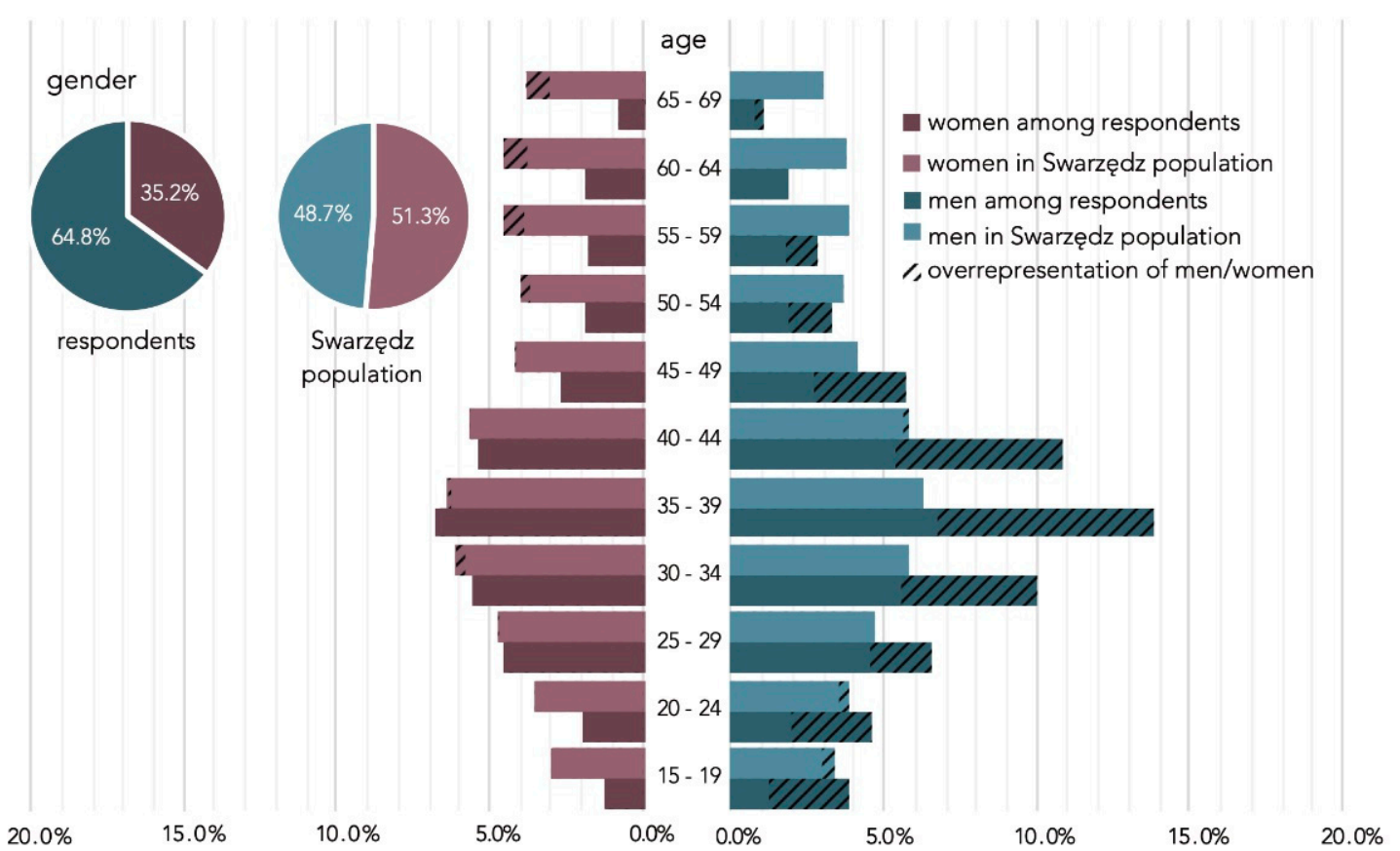

Figure 5. Age and gender structure of respondents in Swarzędz commune. Source: own elaboration based on geoquestionnaire results and statistics Poland data. 


\section{Results}

In accordance with the assumptions of the applied methodology, an in-depth study of the cases chosen was conducted. As a result, the response to the research questions posed in the introduction of the paper was possible. It concerned the stakeholders' motivations to apply a geo-questionnaire in the process (RQ1); the evaluation of the extent to which the results were taken into account in decision making (RQ2); and the role of PPGIS in increasing the level of public participation (RQ3).

\subsection{Motivations for Applying PPGIS in Spatial Planning}

What stands out in the literature, among the general aims of public participation, is the authorities gaining insights into public preferences, so that they can be included in decision making [8]. According to Rowe and Frewer [69], public participation increases the confidence in decision-making processes to ensure social cohesion between various stakeholders. Also, the implementation of legal provisions (obligations) and legitimacy to make public decisions is crucial, also in Poland [21,37,70].

In both the analyzed cases, the motivations for using PPGIS were very similar. They were divided into three groups - quantitative, qualitative, and communicative (Figure 6). Due to their more universal nature, they can be referred to not only to spatial planning, but also to more-general decision-making processes-to local governance. At the top of the interlocutors' answers were the following: reaching a larger number of residents taking part in public consultations' processes, curiosity about new methods and diversification of those already used, and obtaining accurate spatial data. During the interviews, the motivations connected with the creation of a positive image of the authorities and the legitimacy of the preliminary decisions were also mentioned.

\begin{tabular}{|c|c|c|}
\hline \multicolumn{3}{|c|}{ MOTIVATIONS FOR PPGIS USE IN LOCAL GOVERNANCE } \\
\hline QUANTITATIVE & QUALITATIVE & COMMUNICATIVE \\
\hline $\begin{array}{l}\text { - reaching higher number } \\
\text { of participants } \\
\text { targeting new groups } \\
\text { of particpants }\end{array}$ & $\begin{array}{l}\text { - collecting ready-made } \\
\text { spatial data } \\
\text { implementing new method } \\
\text { of public consultations }\end{array}$ & $\begin{array}{l}\text { - obtaining the legitimacy } \\
\text { to make decisions } \\
\text { - creating positive image } \\
\text { of innovative governance } \\
\text { - communicating with } \\
\text { residents to know their } \\
\text { expectations }\end{array}$ \\
\hline
\end{tabular}

Figure 6. Motivations for PPGIS use in decision-making processes. Source: own elaboration.

In the literature, PPGIS approaches are commonly identified with the possibility of reaching the broader public [20]. To reach more residents (especially younger) was one of the main reasons for applying a geo-questionnaire, as the internet is viewed as one of the most effective communication tools nowadays. As one of the mayors stated, "considering the scale of residents who took part in the geo-questionnaire, it was more important to me that we got the vote of people who, I suspect in $80 \%$, would never have made it to the meeting - any meeting. Objectively speaking —if we are talking about young peoplesmall children, both parents are working, earning loans-there is no chance to find this hour and get involved in social matters. I'm not saying it negatively-that's the harsh truth. But at the time of geo-questionnaire there was a time to fill it calmly and it worked". According to the interviewees, the geo-questionnaire was a method with a greater potential to reach residents than the traditional one (paper surveys, meetings in a town hall). Local authorities (especially the heads of spatial planning departments) linked a broader number of respondents with obtaining broader knowledge about residents' needs, preferences, and opinions. It was expected that it would allow verifying and objectifying the primary assumptions of the spatial development of a given area.

The interviewees did not hide their curiosity about the method's possibilities and public feedback on that form of public consultations. An element emphasized during the 
interviews was also the curiosity about how this method will be perceived by residents, and how big their involvement and willingness will be to use this type of online form of consultations. As noted by one of the communes office workers, "at the beginning of the process, I was curious how the residents would react and what their expectations are, and at the same time-what should be in this area". Another aspect that was mentioned during the interviews, which played an important role in the decision to apply the method, was the possibility of collecting accurate and precise spatial data. The officials who participated in the processes also pointed out that the way of collecting spatial data using a PPGIS platform was easier, faster (did not require manually digitizing objects from, e.g., paper maps), and cheaper, as it did not require a public opinion research company to engage with a group of interviewers who would collect data face-to-face.

In a less direct way, local authorities (in both cases, mayors) hinted at PR and the legitimacy of decisions as motivations for using PPGIS. As mentioned by one of the local authorities, "in politics, whatever we do, any tool that shortens the distance to the citizen, that is-the voter, is extremely helpful. After all, it is part of the survey. This is not an election poll-what candidate, what option, or political party you support. But this is such a simple verification that we can imagine, that for example for people today the most important thing is infrastructure. ( . . . ) In terms of PR, you cannot open up more when it comes to administration and ask the residents directly on such a scale of possibilities". Creating a positive image of authorities is one of the key elements of governing (often motivated by re-election concerns); it is often hidden behind actions that are directed towards residents, in the form of public consultations. In both cases, it was clearly visible, because the media were also engaged in the processes. The novelty of the applied method could be a way to present a commune office (and local authorities) as innovative.

The legitimacy of the solutions that were planned before opening the process to the public was an important aspect that shed light on the motivations for using a geoquestionnaire. It was not only observed in both cases of the preparation of the local spatial development plans, but it was also directly mentioned by one of the interviewees, who said that "such results constitute a kind of legitimacy for making decisions". Possible conflicts of interests between the local government (represented by authorities and commune offices), residents, and investors, in terms of the land use of both areas, were the reason for seeking a strong argument supporting the final decisions.

\subsection{Stakeholders' Design Expectations and the Evaluation of Decision-Making Output}

In the case of Rokietnica, a PPGIS tool was used twice in the procedure-at the diagnostic phase and at the end of the design phase (see Figure 1). However, in practice, both implementations of PPGIS took place at the highly advanced stage of decision making. This was due to the fact that the designers (on behalf of local authorities) had already prepared several land use concepts of this area, commissioned by the commune office, before the council adopted a resolution to prepare the plan. Consequently, the results of public consultations did not serve their function. Instead of shaping the initial assumptions of the plan, they were used only as a survey on public opinion, and only affected the choice of one of the preplanned options. The results of the geo-questionnaire that was conducted at the diagnostic phase suggested residents' expectations of lowering the height of the buildings and their type, also including single-family housing (Table 4). However, at the subsequent stage (the end of the design phase), residents using the PPGIS tool expressed their dissatisfaction with the insufficient lowering of the parameters indicated in the previous public consultations. At that stage of the public consultations, the expectations of all the involved parties were confronted with one another, those of residents, landowners, and local authorities (and designers commissioned by the authorities). The latter wanted to limit the financial consequences of the resolution of the local spatial development plan for the commune, and to create attractive and functional urban spaces. 
Table 4. The vision of the development of the New Center of Rokietnica according to the expectations of various stakeholders.

\begin{tabular}{cc}
\hline Feature & Goal \\
\hline
\end{tabular}

Pre-planning local authority's assumptions

\section{Residents' expectations}

Property owners' expectations

Decision-making output (local spatial development plan)
Development of representative and functional center of commune.

Development of widely accessible space with low density residential buildings, public green and recreational spaces, preferences for pedestrians.

Development of profitable high-density multi-family estate.

Balanced development of new center in place of brownfield with reduction in extra costs for commune for reduction of private land value.
Development Details

Land use: residential (multi-family housing) with services and green areas, central area with public square, marketplace, administrative buildings and commercial buildings;

Number of stories: up to 5 stories;

Communication system: roads with preferences for cars;

Parking lots: surface, underground garages;

Trade and services: open air market, premises on ground floor of buildings.

Land use: residential (single- and multi-family housing) and services with green areas and outdoor recreational infrastructure;

Central area with public square, cultural and administrative buildings;

Number of stories: up to 3 stories;

Communication system: roads with reduced traffic, preferences for pedestrians, bicycle lanes;

Parking lots: surface, underground garages, no ground garages;

Trade and services: stands or market hall, premises on the ground floor of buildings.

Land use: residential (multi-family housing) and services;

Number of stories: up to 6 stories;

Communication system: preferences for car traffic;

Parking lots: surface, underground garages;

Trade and services: no information.

Land use: residential (multi-family housing), services and public spaces (green areas, outdoor sport's area).

Administrative and cultural as optional;

Number of stories: up to 5 stories;

Communication system: preferences for car traffic;

Parking lots: surface, underground garages;

Trade and services: stands or market hall, premises on ground floor of buildings.

Source: own elaboration based on public consultation results, interviews, and the analysis of commune office documents.

In the final output of the decision-making process (in the form of commune council's resolutions that were implemented in 2018, 2019, and 2021, for different parts of this area), new residential areas were designed, partially replacing greenery, and all the areas of single-family housing were replaced by multi-family housing. The adopted local plan also assumed green and recreational areas; however, in the final stage of decision making, part of this area was replaced by multi-family housing and eventually it took up a smaller area. What also needs to be emphasized is that the green area in the plan primarily resulted from the terrain conditions occurring there-a high groundwater level precluding the development of buildings - rather than the priorities for the introduction of public green areas with a recreational function, which was postulated by the residents. These changes were only consulted by using traditional methods-presentation to the public with the possibility of sending formal comments.

In regards to the Poznań-Kobylnica airport in Swarzędz (CS2), a geo-questionnaire was carried out in the initial phase, both formally and practically. It resulted in conducting public consultations, in order to reach decisions concerning the need to work out the local 
plan. In this case, it would also be connected with a partial change in the spatial study. Both the method and the obtained results were applied prior to the action on preparing the concept of a local plan. Conducting the geo-questionnaire survey resulted from the plans of property owners (the Poznań Aeroclub) to sell it. The Aeroclub lobbied for changing the designated use from land to logistic (warehouses) purposes (Table 5). Owing to the limitations connected with the transportation accessibility of the area and closeness to single-family housing, the local authorities considered other options as well. Hence, the geo-questionnaire was used for surveying the public opinion on the future development of that area. It was found that the public was against the mono-function lobbied by the Aeroclub, i.e., warehouse storage, which was in line with the standpoint of the local government. Most people were in favor of continuing the single-family housing function, or formally introducing a recreational function; however, the latter was unfeasible, due to the economic value of the land. The public consultations' results supported the decision to change the spatial study and launch the formal process. On the other hand, they were used as an argument against potential investors' plans and their expectations regarding the function of this area, rather than meeting the citizens' expectations. In fact, the concept devised by a private architecture company, presented by the local authorities, proposed much more intensive, multi-family housing, allowing high-rise buildings. The author of the local plan concept argues that tall buildings will free space for greenery and recreation that would be seized by an estate of single-family houses, which resembles the ideas created by modernist architects. The architect reassures that the so-called "island of towers" is to be a self-sufficient enclave, rich in modern pro-ecological solutions. However, the issues of access, service, and the impact of high buildings on the surroundings and nature, are controversial, as is the sense of the entire project in a suburban village.

Table 5. The vision of the development of the New Center of Rokietnica according to the expectations of various stakeholders.

\begin{tabular}{l} 
Feature \\
\hline $\begin{array}{l}\text { Pre-planning local authority's } \\
\text { assumptions }\end{array}$
\end{tabular}
assumptions

Residents' expectations

Property owners' expectations

Decision-making output (concept of local spatial development plan)
Blocking investors' plans to introduce warehouses and production in area.

Development of low-density residential area with greenery and recreation.

Development of functions interesting for potential investor-warehouses or production.

Development of area so that it is accepted by investors; however, excluding warehouses and production functions.

\section{Development Details}

Land use: different than warehouses or production; Number of stories: not specified; Communication system: not specified; Trade and services: not specified.

Land use: residential, single-family housing estate with greenery and recreation;

Number of stories: up to 2;

Communication system: connection of nearest estates and construction of collision-free railway crossings;

Trade and services: as additional function.

Land use: warehouses and production function; Number of stories: not specified;

Communication system: not specified;

Trade and services: no.

Land use: high-density multi-family housing with services;

Number of stories: admission of high-rise buildings; Communication system: communication system limited only to servicing estate with one access road; Trade and services: not specified.

Source: own elaboration based on public consultation results, interviews, and the analysis of commune office documents.

In the case of Swarzedz, the most important observed result of the consultations was the development of arguments against the investor's plans. It can be stated that this result was, in a way, an intended goal of the use of PPGIS. On the one hand, as a result of the process, the commune office presented a clear position against the introduction of a logistic function in this area, but, on the other hand, the intensity of housing development proposed 
in the concept was in contrary to the respondents' postulates. As in the case of Rokietnica, the proposed solutions were a kind of compromise between the interests of the investor, the commune authorities, and the local residents, but, on the other hand, the process was of a different nature. The discussions and debates that took place, both in the media and at the meetings of the commune council, were also important here. Investors referred to the results of the geo-questionnaire, undermining the credibility of its participants (due to, inter alia, their anonymity and uncertainty of the actual connection with this area). In turn, representatives of the commune office used the statistics on the expectations of respondents in discussions and negotiations with investors. The impact of using PPGIS is very well reflected in the words of one of the representatives of the commune office, "owners of the area in their presentation at city hall presented that they actually saw the logistics and warehouse function there, trying to prove that it was a better solution, but then they remain silent. Maybe they realized that our idea, plus suggestions from residents, showed that there is no discussion (...). There was such a peak at one point-in newspapers, in television, and after this geo-questionnaire consultations and presentation of the results, the topic became quiet".

The presented results show that the direct impact of public consultation results on design solutions was minor. The reasons for this should be observed in the role of space among the various stakeholders, and the opportunities (formal and informal) they have in the decision-making process (Figure 7). For residents, local physical space determines the quality of life-its changes may translate into the improvement or decline in it [71-73]. The residents' goals, as was observed in the two presented examples, was to protect the previous quality of life. The residents' activities in decision making include legally regulated participation in the process (submitting proposals and comments to the project), or other forms of participation that are dependent on the local authorities. Residents (as individuals or groups) who have objections to the results of the process may also appeal to higher instances. In both the analyzed cases, the local authorities goal was to create a space that would be acceptable to residents, while minimizing the risk of the investor's compensation claims. Applying legal provisions and the implementation of informal ways of communication with stakeholders, are two ways to achieve this goal by local authoritieswhich also took place in the investigated processes. For local authorities, decision-making processes are also - taking into account a re-election - a political process. For the last group of the mentioned stakeholders-investors-economic space is primarily perceived as the source of financial profits. Similarly to residents, they can submit proposals and comments to the project, and submit appeal to higher instances. Nonetheless, the lobbying among local authorities, and the attempts to build a consensus with local authorities, play an equally important role.

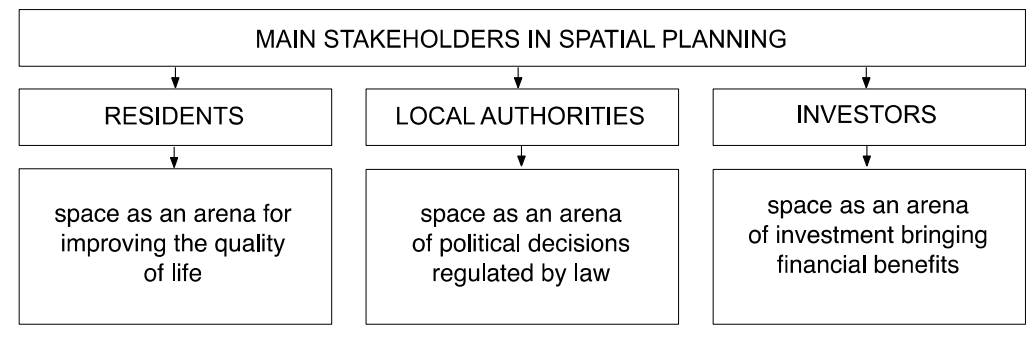

Figure 7. The importance and role of space among different stakeholders in the process of spatial development. Source: own elaboration.

Despite the minor direct impact that the residents had on decisions in the opinion of local authorities from both communes, the use of PPGIS played a very important role in the whole process. It was connected with reaching a higher than usual number of residents who participated in the process. Quoting one of the authorities, "one thing that surprised me very positively, which in retrospect may seem obvious, is the power of democracy in this tool. More specifically - if we later talked to the commune council about this plan, no 
one had the strength to question the plan, since it was so widely consulted". This statement shows how important, thus useful, the quantitative involvement of residents can be during public consultations for decision makers. In other words, especially considering the final evaluation of both the processes, the quantitative participation is prior to the qualitative engagement of citizens in decision making.

\subsection{The Rrole of PPGIS in Citizens' Involvement in Decision Making}

In the case of Rokietnica, the local spatial development plan for the area covered by public consultations was a kind of compromise between the expectations of the residents, and the interests and previous investment opportunities of the landowners, as in the situation when there is no valid local spatial development plan, investments should relate to the buildings in the area. Due to the regulations on the basis of which the landowner may claim compensation for the decline in the value of the property, the local authorities had to take into account the financial consequences of adopting the plan, i.e., the costs for the commune and, therefore, the costs for the local community. On the other hand, the commune authorities wanted to create a representative part of the village, where, ultimately, administrative and cultural services could also be found, which, according to the architectural concept, could be achieved by gradually increasing the height of buildings towards the center of the area. The use of PPGIS allowed the knowledge of decision makers, about the expectations of the residents, to be broadened. Ultimately, it was a survey of the residents' opinions. Despite the fact that the geo-questionnaire made it possible to determine the expectations of residents very specifically, regarding the development of the area, in general and in relation to detailed parameters in specific locations, key decisions were made at the stages of the decision-making process carried out without, or with a limited (minimally required by law) participation of, the residents. This concerned the following:

1. The initial stage of the process (before the initiation of public consultation);

2. The final stage of the process-carried out behind closed doors (between decision makers, urban planners, and landowners) and/or with the use of statutory forms of public consultation only, thus excluding the wider participation of residents.

On the example of these processes, it can be concluded that the expectations of investors, and thus the possible financial consequences of the adoption of the plans, played the most important role, and the influence of the residents' voice on the future development of the area was marginal.

It has to be stated that the role of PPGIS in both the processes, according to Arnstein's ladder of participation, was an example of tokenism-when citizens provided with an opportunity to express their needs and opinions have, in fact, a minor influence on the decisions. On the example of the New Center of Rokietnica, it can be observed that the opportunity to engage a greater number of citizens in the process (because of its online form) might be interpreted as an action presenting a decision-making process as transparent and open, which had to be confronted with the local authorities' possibilities of spatial development being limited by the law. On the other hand, the case of the Poznan-Kobylnica airport in Swarzedz was a different example of tokenism. In this process, the rather high (in number) engagement of citizens in public consultations that were conducted with the use of PPGIS, allowed an argumentation to be built against the initial investors' plans for the future land use of the area. However, the results of the public consultations were not directly reflected in following the local authorities' concept for the future development of the area. Despite the fact that plans are connected with residential development (which was in line with the public consultation results), the density and type of buildings (mainly high multi-family housing) are the opposite of the geo-questionnaire results. The results of the consultations (and thus the PPGIS use in the process) were used by the local authorities to block the investor's attempts.

With reference to the IAP2 classification mentioned in the section on the research methodology in the analyzed cases, public participation reached the second of the five 
levels, which is "consult", in which, according to Nyergess et al. [68], the public is informed and they provide feedback. The issue of the role of PPGIS in raising the level of public participation, to increase the quality and ensure better consolidation of decisions in spatial planning, is of key importance for the essence of the method [20]. However, the obtained results, based on the long-term observation and analysis of decision-making processes in legal procedures of spatial development, confirmed the observations carried out previously by Babelon et al. [74], pointing to a lower-than-expected level of public participation in public consultation processes. On the one hand, it may question the importance of PPGIS in participatory planning, but, on the other, it draws attention to the need to look for the causes of such a situation, which, according to the authors, are independent of the method itself, but are the results of the legal conditions, maturity of the management systems in the local governments, and proper organization of the process. However, it also raises a question on the role of PPGIS in decision-making processes in spatial planning and in local governance in general.

\section{Discussion}

Local governance is based on decision making resulting from the calculation of costs and benefits, as well as the efficiency of the actions (including lobbying) of the actors involved [7]. Therefore, leadership and related characteristics, which refer to communication skills apart from the motivation to manage, are of significance [15]. An in-depth analysis of two decision-making processes showed that PPGIS helped to build an argumentation against investors. Also, it was viewed as a tool that allowed shortening of the distance to residents - voters - and engagement of a wider group of participants. However, in the literature, those aspects - if prioritized-are heavily criticized as a way of manipulating, rather than empowering, society $[9,75,76]$.

The research results do not show the role of PPGIS in increasing the qualitative level of public participation. However, the expectations of the local authorities connected with the engagement of a higher number of participants were met. Nonetheless, the organization of the public consultations focused on reaching a higher number of residents, and the legitimacy of the decisions already taken or minor changes to the project are a typical examples of tokenism. It is often the case that such pseudo-consultations are used to legitimize the assumptions already made by local authorities at the beginning of the process. This is a result of legal requirements, rather than the genuine participation of citizens in spatial planning.

A factor that could have resulted in the limited incorporation of the results in decision making could be inappropriate assumptions of the role of a public participation process, which focused on increasing the number, and not the level, of the participation of residents in decision making. Even if the results of the consultations were included in the decisions, it was only to the extent that was consistent with the initial design assumptions. As a result, the tool was only used as a formal extension of the catalog of consultation methods, and as a quantitative confirmation of the opinion of the residents who participated in the processes, assumed before the consultations. The analysis of both cases makes it possible to conclude that the potential role of PPGIS in empowering residents in spatial planning processes with a high investment value of private property will be marginal. This situation is primarily influenced by legal regulations, which place the private interests of the owner above public interest, resulting in a limited role of citizens in the decision-making process in general. Achieving society's empowerment in the field of spatial planning is also difficult, taking into consideration common social, economic, and environmental goals. This is especially the case when citizens' knowledge about the consequences of decisions regarding space is poor, and territorial governance is motivated by re-election concerns.

In both the analyzed processes, owing to private ownership and formally restricted access to the areas, it was limited to collecting a unique residents knowledge on the current spatial development. It is assumed that it could significantly improve residents' input, and, as a consequence, participation in the decisions made. The examples presented in 
the literature show the more-effective use of PPGIS in decision-making processes that are dedicated to urban design, in a scale in which residents' knowledge about the area, collected through PPGIS tools, plays a very significant role $[75,77]$.

Even though the use of PPGIS did not upgrade the level of public participation in either of the analyzed cases, the use of a geo-questionnaire and the obtained results were important for decision makers. Increasing the number of residents who take part in public consultations was the primary feature of the conducted processes (Figure 8).

\begin{tabular}{|c|c|c|}
\hline $\begin{array}{c}\text { PPGIS use } \\
\text { in spatial planning }\end{array}$ & leeds to & $\begin{array}{c}\text { greater number } \\
\text { of participants in public consultations } \\
\text { in spatial planning }\end{array}$ \\
\hline & & helps to \\
\hline $\begin{array}{l}\text { - building stronger argumentation in } \\
\text { negotiations with investors } \\
\text { - awareness on the possible conflicts } \\
\text { of interests } \\
\text { - greater interest of residents in the } \\
\text { results of the decision-making process } \\
\text { - better social acceptance and } \\
\text { understanding of decisions } \\
\text { - more residents' oriented local policy }\end{array}$ & results in & $\begin{array}{l}\text { - diagnose citizens' expectations } \\
\text { - collect citizens' knowledge about the } \\
\text { area and their habits connected with } \\
\text { the current use of the site } \\
\text { - know general residents' needs } \\
\text { according to spatial development } \\
\text { of the municipality } \\
\text { - raise residents' awareness on } \\
\text { spatial planning }\end{array}$ \\
\hline
\end{tabular}

Figure 8. The role of PPGIS in decision making in local governance. Source: own elaboration.

PPGIS as an online public consultation method that enabled easier access to the process, and thus wider public participation. When citizens' participation in public consultations regarding spatial planning is very low, PPGIS helped to involve them in the process, and also, in consequence, raised greater awareness to the consulted issues. The results, even if not directly implemented, might be of great importance from the perspective of local governance-according to the general trends of local development and residents' needs. Reaching a broader group of residents allows local authorities to address their expectations and observed trends in their decisions concerning the whole commune (local policy, development strategies). Building an argumentation in negotiations with investors and local councils was the most direct impact of the use of PPGIS in both cases. Whenever investment plans may reduce the quality of space and the living conditions of residents, objections that are raised by a large number of respondents may be a strong argument. Reports from public consultations that were based on such a turnout of residents were indisputable. However, it has to be claimed that the results of public consultations are secondary to the legal regulations defining investment opportunities. Nonetheless, according to the interviewees, the geo-questionnaires results played an important role in consensus building with investors.

The impact of the information obtained from residents on the decision-making process is one of the most important criterion, justifying the role of PPGIS [78,79]. When analyzing PPGIS implementation in public consultations, it can be concluded that the use of the results was influenced by aspects such as the following: striving for a positive assessment of the authorities by residents (owing to a wider public consultation process), financial consequences of the decisions (which is characteristic of local spatial development plans), and convergence with the spatial planning policy and vision of the authorities. Thus, in the case of the decisions concerning strategic areas of commune development, PPGIS should have a complementary and auxiliary role, but, at the same time, it is necessary to emphasize and inform the public, at the beginning of such a process, on what the decision-making possibilities (frameworks) are, as well as the conditions and effects (including financial) of specific solutions.

Even if the analysis of case studies was conducted in the Polish legislative and administrative context, the results are of a more universal nature, connected with the governance 
model and the administrative culture characteristic of most European democratic countries. It indicates the current trends in governance reforms towards more participatory and open decision-making processes that, apart from the digitalization of administration, is one of the main paths for local government organizational development [10]. In terms of spatial planning, this is especially the case in countries with a similar development path $[80,81]$. The results indicate that an application of PPGIS in planning processes is mainly a technical and organizational procedure, while the implementation of the results into decisions depends on the stakeholders' interests (manifested, for example, in lobbying) and the economic consequences of the decisions taken. For this reason, according to the authors, despite the growing number of PPGIS uses, the application of these methods is primarily justified in terms of public areas (commune property), where the spatial development directions are not limited by the investor's financial interests, and the decision-making process is focused on the needs and expectations of local communities. For this reason, despite the potential of the aforementioned advantages of PPGIS, such as supporting argumentation against undesirable land use, reaching a larger number of younger residents, and the technical facilitation of participation in public consultations, the decision to use PPGIS should be preceded by a question about the extent to which the voice of the residents will affect the decisions. If this impact is limited (through legal, environmental, or ownership issues), the use of PPGIS will play only a diagnostic role, which significantly undermines the principles of this method [36,52-57]. Despite the expectations related to the development of PPGIS, i.e., offsetting the deficits of traditional methods of public participation, the aspect of the residents' influences on the decisions made is still a significant challenge that PPGIS has not yet met.

\section{Conclusions}

The conducted analysis showed that PPGIS tools were used to collect information on the preferences of residents on a much larger scale than would be possible with traditional (legally determined) methods. This was the main motivation for applying the method by local authorities in both Rokietnica and Swarzędz (research question 1). The obtained results were, on the one hand, an argument in negotiations with investors or local councilors, and, on the other, they made it easier for residents to participate in consultations (research question 2). The obtained results of the public consultations constituted a form of survey or diagnostic material, rather than a source of decisions that were made. The awareness of the representation (also spatial) of participants providing the information about who participated in the consultations, and, therefore, whose voice was expressed, was also important in building the argumentation. The aspect of participants' representativeness is crucial in the discussion of the significance of the results obtained from any consultation process $[24,82]$.

The obtained results led to the conclusion that the use of PPGIS in the processes similar to the analyzed case studies does not have a significant impact on increasing the level of public participation in the decision-making process, i.e., to the level of collaboration or empowerment according to the IAP2 classification (research question 3). Similar results were obtained by Babelon et al. [74], who identified the achievement of consultation or involvement levels, which are therefore possible to be achieved by means of the commonly used forms of citizens' engagement. The obtained results of the use of PPGIS in both cases were a higher number of participants, which allowed an argumentation to be built in negotiations with investors. Such results were the consequence of the national law related to public participation in Poland, according to which local authorities are not obliged to implement the results of public consultations in their decisions, and which indicates, as obligatory forms of public consultations, solutions that are commonly deemed ineffective. Consequently, PPGIS is neither a universal and legally valid form of public consultation (which also does not apply in other countries), nor are the results that will be obtained required to be implemented. Therefore, PPGIS is primarily a diagnostic tool. In order to increase the importance of PPGIS in spatial planning processes, it is essential to properly 
select this method for the subject and area of consultations, i.e., the spatial development of which will depend on the expectations of the residents, and its implementation will be feasible in such a form.

The importance of public participation in spatial planning may be increased with the use of effective fiscal tools (for example, solutions at the level of national law related, inter alia, to the costs of decisions, such as compensation for land owners, which significantly determines the directions of decisions made by local authorities) and methods of resolving conflicts of interest through mediation and deliberation. The use of tools such as the geo-questionnaire, under the conditions of neoliberalism in spatial planning and with established strong urban regimes, will be limited in terms of their effectiveness [15,39]. Nevertheless, the changing governance models at the local levels, the terms of the office of the authorities, and the importance of public relations (including communication with residents using digital tools) impact the growing motivations of local authorities related to re-election, and thus the response to citizens' expectations that can be expressed more comprehensively through PPGIS.

The two case studies presented indicate the limitations and possibilities of using PPGIS in the field of a broadly understood formal (legally regulated) spatial planning, but also informal—urban architecture designs that are typical of so-called preplanning processes, or studies related to the identification of local community needs at the neighborhood scale (street, quarter). Including PPGIS in the process of public participation supports the involvement of wider communities who are interested in the planning process. Residents are an inestimable source of knowledge about local matters, which is not always available to decision makers. Authorities, urban planners, and those responsible for the local development, by giving residents the opportunity to participate in public consultations via the internet, can gain access to a much larger number of people, and thus increase the public interest in local issues. Along with the development of governance models in local self-governments that are aimed at co-management and co-decision making, authorities aim to obtain real legitimacy to take specific actions.

The widespread adoption of online PPGIS tools, such as a geo-questionnaire, as a standard element of public consultations, requires dealing primarily with legal and organizational barriers. The technological progress and improvement of PPGIS tools does not yet determine the success of their use in decision-making processes in spatial planning. Owing to the legal regulations that do not provide residents with an actual role in decisionmaking processes, the implementation of PPGIS is basically only associated with additional optional methods of extending the scope of socialization of the procedure for preparing spatial planning documents. This is related to the dependence of the acceptance of the results of such consultations on the current interests, priorities of the authorities of the units in which they were conducted, and the adopted local law. For the purposes of conducting participatory processes, it is especially necessary to involve residents in the design phase, in which the initial concepts of the project are created. This provides an opportunity to exchange views with designers and often allows for the elimination or reduction in conflicts related to changes in spatial development. The implementation of PPGIS also requires significant organizational regulations connected, inter alia, with increasing the competences of office employees or imposing any additional obligations on them. Similarly to the implementation of each innovation, especially such that is technologically advanced, the dissemination of PPGIS in planning practice requires changes in the socio-economic and legal environment. As Ganapati [27] points out, the greatest limitations in the use of PPGIS do not result from technological possibilities, but from institutional and organizational conditions. Focusing, in the process of the use of PPGIS, primarily on technology and a greater number of participants, instead of the involvement of residents, will have a negative impact on the implementation of the principal goals of PPGIS.

Author Contributions: Conceptualization, E.B.-W.; methodology, E.B.-W.; validation, E.B.-W. and T.K.; formal analysis, E.B.-W.; investigation, E.B.-W. and T.K.; resources, E.B.-W.; data curation, E.B.-W.; writing—original draft preparation, E.B.-W. and T.K.; writing—review and editing, E.B.-W. 
and T.K.; visualization, E.B.-W.; supervision, E.B.-W.; project administration, E.B.-W. All authors have read and agreed to the published version of the manuscript.

Funding: This research was supported by National Research and Development Center (Narodowe Centrum Badań i Rozwoju), grant number PBS3/A9/39/2015.

Institutional Review Board Statement: Ethical review and approval were waived for this study, due to the use of standard research methods for social sciences, i.e., in-depth interview among public authorities and an anonymous voluntary questionnaire. The research standards were maintained during the research, i.e., the anonymity of the participants (except public authorities) was maintained and their physical, social and mental condition was not interfered with.

Informed Consent Statement: Informed consent was obtained from all subjects involved in the study.

Data Availability Statement: New data created in this study are not publicly accessible. Transcripts from the interviews and datasets related to the demographic structure of PPGIS users can be presented on request.

Acknowledgments: The authors gratefully acknowledge the support of the Rokietnica Commune Office and Swarzędz Commune Office in conducting the research.

Conflicts of Interest: The authors declare no conflict of interest.

\section{References}

1. Healey, P. Institutionalist analysis, communicative planning, shaping places. J. Plan. Educ. Res. 1999, 19, 111-121. [CrossRef]

2. Izdebski, H. Nowe kierunki zarządzania publicznego a współczesne kierunki myśli polityczno-prawnej. In Nowe Zarządzenie Publiczne i Public Governance w Polsce i w Europie; Bosiacki, A., Izdebski, H., Nielicki, A., Zachariasz, I., Eds.; Liber: Warsaw, Poland, 2010; pp. 12-27.

3. Izdebski, H. Samorząd Terytorialny. Podstawy Ustroju i Działalności; LexisNexis: Warsaw, Poland, 2011.

4. Quick, K.S.; Bryson, J. Theories of public participation in governance. In Handbook in Theories of Governance; Torbing, J., Ansell, C., Eds.; Edward Elgar Press: Cheltenham, UK, 2016; pp. 158-169.

5. Banyan, M.E. Participation. In Encyclopedia of Governance; Bevir, M., Ed.; Sage Publications: Thousand Oaks, CA, USA, 2007; pp. 659-663.

6. Bryson, J.M.; Quick, K.S.; Slotterback, C.S.; Crosby, B.C. Designing public participation processes. Public Adm. Rev. 2013, 73, 23-34. [CrossRef]

7. Haughton, G.; Allmendinger, P.; Counsell, D.; Vigar, G. The New Spatial Planning: Territorial Management with Soft Spaces and Fuzzy Boundaries; Taylor \& Francis: London, UK, 2010.

8. Innes, J.E.; Booher, D.E. Reframing public participation: Strategies for the 21st century. Plan. Theory Pract. 2004, 5, 419-436. [CrossRef]

9. Kingston, R.; Carver, S.; Evans, A.; Turton, I. Web-based public participation geographical information systems: An aid to local environmental decision-making. Comput. Environ. Urban Syst. 2000, 24, 109-125. [CrossRef]

10. Denters, B. Participation and democratic accountability: Making a difference for the citizens. In The Future of Local Government in Europe Lessons from Research and Practice in 31 Countries; Schwab, C., Bouckaert, G., Kulhmann, S., Eds.; Nomos Verlagsgesellschaft: Baden-Baden, Germany, 2017; pp. 79-100.

11. UNDP. Defining Core Characteristics of Good Governance. United Nations Development Programme, Management Development and Governance Division, Strengthening Capacity for People-Centred Development; UNDP: New York, NY, USA, 1997.

12. Allmendinger, P. Planning Theory; Palgrave Macmillan: New York, NY, USA, 2009.

13. Osborne, S.P. The New Public Governance? Emerging Perspectives on the Theory and Practice of Public Governance; Routledge: London, UK, 2010.

14. Thomson, M. What's so new about New Municipalism. Prog. Hum. Geogr. 2001, 45, 317-342. [CrossRef]

15. Sagan, I.M. Nowa Kwestia i Nowa Polityka; Wydawnictwo Naukowe Scholar: Warsaw, Poland, 2017.

16. Szczepańska, A. Procesy decyzyjne w gospodarce przestrzennej. Space Soc. Econ. 2009, 9, 43-51.

17. Talen, E. Bottom-Up GIS: A new tool for individual and group expression in participatory planning. J. Am. Plan. Assoc. 2000, 66, 279-294. [CrossRef]

18. Haklay, M.; Tabón, C. Usability evaluation and PPGIS: Towards a user-centred design approach. Int. J. Geogr. Inf. Sci. 2003, 17, 577-592. [CrossRef]

19. Sieber, R. Public Participation Geographic Information Systems: A literature review and framework. Ann. Assoc. Am. Geogr. 2006, 96, 491-507. [CrossRef]

20. Brown, G.; Kyttä, M. Key issues and research priorities for public participation GIS (PPGIS): A synthesis based on empirical research. Appl. Geogr. 2014, 46, 122-136. [CrossRef] 
21. Bakowska, E.; Kaczmarek, T.; Jankowski, P.; Zwoliński, Z.; Mikuła, Ł.; Czepkiewicz, M.; Brudka, C. Geo-questionnaire in urban planning-Preliminary results of the experimental application in Poland. Rozw. Reg. I Polityka Reg. 2016, 35, 9-26.

22. Jankowski, P.; Forss, K.; Czepkiewicz, M.; Saarikoski, H.; Kahila, M. Assessing impacts of PPGIS on urban land use planning: Evidence from Finland and Poland. Eur. Plan. Stud. 2021, 1-20. [CrossRef]

23. Falco, E. Digital community planning: The open source way to the top of Arnstein's Ladder. Int. J. E-Plan. Res. 2016, 5, 1-22. [CrossRef]

24. Tulloch, D.L.; Shapiro, T. The intersection of data access and public participation: Impacting GIS users' success? Urban Reg. Inf. Syst. Assoc. (URISA) 2013, 15, 55-60.

25. Schlossberg, M.; Shuford, E. Delineating "public" and "participation" in PPGIS. Urban Reg. Inf. Syst. Assoc. 2005, 16, 15-26.

26. Kaczmarek, T.; Wójcicki, M. Participation in public consultations on spatial planning documents. The case of Poznań City. Quaest. Geogr. 2016, 35, 71-82. [CrossRef]

27. Ganapati, S. Using geographic information systems to increase citizen engagement. IBM Center for the Business of Government. Public Adm. Rev. 2010, 3, 425-434.

28. Arnstein, S.R. A ladder of citizen participation. J. Am. Inst. Plan. 1969, 35, 216-224. [CrossRef]

29. Wiedemann, P.M.; Femers, S. Public participation in waste management decision making: Analysis and management of conflicts. J. Hazard. Mater. 1993, 33, 355-368. [CrossRef]

30. Dorcey, A.H.J. Public Involvement in Government Decision Making: Choosing the Right Model; Report of the B.C.; Round Table on the Environment and the Economy: Victoria, BC, Canada, 1994.

31. Schapp, L.; Edwards, A. Local governance. In Encyclopedia of Governance; Bevir, M., Ed.; Sage Publication: Thousand Oaks, CA, USA, 2007; pp. 663-667.

32. Flyvbjerg, B. Making Social Science Matter: Why Social Inquiry Fails and How It Can Succeed Again; Cambridge University Press: Cambridge, UK, 2018.

33. Healey, P. Collaborative Planning. Shaping Places in Fragmented Societies; McMillan Press Limited: Hampshire, UK; London, UK, 1997.

34. Taylor, N. Anglo-American town planning theory since 1945: Three significant developments but no paradigm shifts. Plan. Perspect. 1999, 14, 327-345. [CrossRef] [PubMed]

35. Kahila, M.; Kyttä, M. SoftGIS as a bridge builder in collaborative urban planning. In Planning Support Systems: Best Practices and New Methods; Geertman, S., Stillwell, J., Eds.; Springer: Dodrecht, The Netherlands, 2009; pp. 389-412.

36. Parysek, J.J. Wprowadzenie do Gospodarki Przestrzennej; Wydawnictwo Naukowe UAM: Poznań, Poland, 2007.

37. Herbst, K. Partycypacja a prawo do miasta. In Partycypacja Społeczna w Planowaniu Przestrzennym; Urząd m.st. Warszawy: Warsaw, Poland, 2014; pp. 7-15.

38. Simaõ, A.; Densham, P.J.; Haklay, M. Web-based GIS for collaborative planning and public participation: An application to the strategic planning of wind farm sites. J. Environ. Manag. 2009, 90, 2027-2040. [CrossRef] [PubMed]

39. Masik, G. Neoliberalizm w polityce przestrzennej dużych miast. In Miasto w Dobie Neoliberalnego Urbanizmu; Szmytkowska, M., Sagan, I., Eds.; Wydawnictwo Uniwersytetu Gdańskiego: Gdańsk, Poland, 2012; pp. 211-221.

40. Wójcicki, M. Formy i Zakres Partycypacji Społecznej w Procesie Planowania Przestrzennego w Poznaniu; Bogucki wydawnictwo Naukowe: Poznań, Poland, 2018.

41. Burton, P. Power to the people? How to judge public participation. Local Econ. 2004, 19, 193-198. [CrossRef]

42. Manzo, C.L. Beyond house and haven: Toward a revisioning of emotional relationships with places. J. Environ. Psychol. 2003, 23, 47-61. [CrossRef]

43. Obermeyer, N.J. The evolution of public participation GIS. Cartogr. Geogr. Inf. Syst. 1998, 25, 65-66. [CrossRef]

44. Brown, G. Public Participation GIS (PPGIS) for regional and environmental planning: Reflections on a decade of empirical research. URISA J. 2012, 24, 7-18.

45. Mukherjee, F. Public participatory GIS. Geogr. Compass 2015, 9, 384-394. [CrossRef]

46. Ganapati, S. Uses of public participation geographic information systems applications in e-government. Public Adm. Rev. 2011, 71, 425-434. [CrossRef]

47. Panek, J. From mental maps to geoparticipation. Cartogr. J. 2016, 53, 300-307. [CrossRef]

48. Parysek, J.J. Podstawy Gospodarki Lokalnej; Wydawnictwo Naukowe UAM: Poznań, Poland, 2001.

49. Pánek, J.; Pásztó, V.; Burian, J.; Bakule, J.; Lysek, J. What is the current state of geoparticipation in Czech municipalities? GeoScape 2021, 15, 90-103. [CrossRef]

50. Ghose, R. Politics of scale and networks of association in public participation GIS. Environ. Plan. A 2007, 39, 1961-1980. [CrossRef]

51. Elwood, S.; Ghose, R. PPGIS in community development planning: Framing the organizational context. Cartographica 2001, 38, 19-33. [CrossRef]

52. Niewiadomski, Z. Planowanie Przestrzenne. Zarys Systemu; Wydawnictwo Prawnicze LexisNexis: Warsaw, Poland, 2002.

53. Kożuch, B.; Markowski, T. Z Teorii i Praktyki Zarządzania Publicznego; Fundacja Współczesne Zarządzanie: Białystok, Poland, 2005.

54. Jędraszko, A. Gospodarka Przestrzenna w Polsce Wobec Standardów Europejskich, Czyli Jak Ustanowić Dobre prawo dla Zrównoważonego Rozwoju; Biblioteka Urbanisty: Warszawa, Poland, 2008.

55. Pawłowska, K. Idea i Metody Partycypacji Społecznej w Ochronie Krajobrazu i Kształtowaniu Przestrzeni; Fundacja Partnerstwo dla środowiska: Kraków, Poland, 2010. 
56. Kaczmarek, T.; Wójcicki, M. Uspołecznienie procesu planowania przestrzennego na przykładzie miasta Poznania. Ruch Praw. I Socjol. 2015, 77, 219-236. [CrossRef]

57. Kotus, J.; Sowada, T. Behavioural model of collaborative urban management: Extending the concept of Arnstein's ladder. Cities 2017, 65, 78-86. [CrossRef]

58. Izdebski, H.; Nelicki, A.; Zachariasz, I. Zagospodarowanie Przestrzenne. Polskie Prawo na tle Standardów Demokratycznego Państwa Prawnego; Ernst \& Young: Warsaw, Poland, 2007.

59. Zachariasz, I.; Nelicki, A. Skuteczność planowania przestrzennego na poziomie lokalnym a partycypacja społeczna. Zarz. Publiczne 2008, 2, 97-108.

60. Brown, G.; Kyttä, M. Key issues and priorities in participatory mapping: Toward integration or increased specialization? Appl. Geogr. 2018, 95, 1-8. [CrossRef]

61. Yin, R.K. Case Study Research: Design and Methods; SAGE: Thousand Oaks, CA, USA, 2003.

62. Czepkiewicz, M.; Jankowski, P. Analizy przestrzenne w badaniach nad jakością życia w miastach. Ruch Praw. Ekon. I Socjol. 2015, 1, 101-117. [CrossRef]

63. Jankowski, P.; Kaczmarek, T.; Zwoliński, Z.; Bąkowska-Waldmann, E.; Brudka, C.; Czepkiewicz, M.; Mikuła, Ł.; Młodkowski, M. Zastosowanie Aplikacji Geoankiety i Geodyskusji w Partycypacyjnym Planowaniu Przestrzennym-Dobre Praktyki; Bogucki Wydawnictwo Naukowe: Poznań, Poland, 2018.

64. Nikodemska-Wołowik, A.M. Jakościowe Badania Marketingowe; PWE: Warszawa, Poland, 1999.

65. Nicpoń, M.; Marzęcki, R. Pogłębiony wywiad indywidualny w badaniach politologicznych. In Przeszłość-TeraźniejszośćPrzyszłość: Problemy Badawcze Młodych Politologów; Mikucka-Wójtowicz, D., Ed.; Libron: Kraków, Poalnd, 2010 ; pp. $245-252$.

66. Bowen, G.A. Document Analysis as a Qualitative Research Method. Qual. Res. J. 2009, 9, 27-40. [CrossRef]

67. International Association for Public Participation. Spectrum of Public Participation. 2015. Available online: https://cdn.ymaws. com/www.iap2.org/resource/resmgr/pillars/Spectrum_8.5x11_Print.pdf (accessed on 30 June 2021).

68. Nyerges, T.; Jankowski, P.; Tuthill, D.; Ramsey, K. Collaborative water resource decision support: Results. Ann. Assoc. Am. Geogr. 2006, 96, 699-725. [CrossRef]

69. Rowe, G.; Frewer, L.J. Public Participation Methods: A Framework for Evaluation. Sci. Technol. Hum. Values 2000, 25, 3-29. [CrossRef]

70. Bąkowska-Waldmann, E.; Kaczmarek, T. The use of geo-questionnaire in spatial planning: Experience from Poland. Int. J. E-Plan. Res. 2019, 8, 45-67. [CrossRef]

71. Mizgajski, A.; Walszek, M.; Kaczmarek, T. Determinants of the Quality of Life in the Communes of the Poznań Aggloemration: A Quantitative Approach. Quaest. Geogr. 2014, 33, 67-80. [CrossRef]

72. Mouratidis, K. Urban planning and quality of life: A review of pathways linking the built environment to subjective well-being. Cities 2021, 115, 103229. [CrossRef]

73. Pfeiffer, D.; Cloutler, S. Planning for Happy Neighborhoods. J. Am. Plan. Assoc. 2016, 82, 267-279. [CrossRef]

74. Babelon, I.; Panek, J.; Falco, E.; Reinout, K. 50 shades of geoparticipation. In ISPM Conference: Let the People Map. Book of Abstracts; Aalto University: Helsinki, Finland, 2019.

75. Kahila-Tani, M.; Kytta, M.; Geertman, S. Does mapping improve public participation? Exploring the pros and cons of using public participation GIS in urban planning practices. Landsc. Urban Plan. 2019, 186, 45-55. [CrossRef]

76. Kotus, J.; Rzeszewski, M. Online mapping platforms: Between citizen-oriented and research-focused tools of participation? J. Plan. Educ. Res. 2020, 1-30. [CrossRef]

77. Elwood, S. Negotiating knowledge production: The everyday inclusions, exclusions, and contradictions of Participatory GIS research. Prof. Geogr. 2006, 58, 197-208. [CrossRef]

78. Brown, G.; Chin, S.Y.W. Assessing the effectiveness of public participation in neighbourhood planning. Plan. Pract. Res. 2013, 28, 563-588. [CrossRef]

79. Kahila-Tani, M. Reshaping the Planning Process Using Local Experiences: Utilising PPGIS in Participatory Urban Planning. Ph.D. Thesis, Aalto University, Helsinki, Finland, 2015.

80. Nunes Silva, C.; Buček, J. (Eds.) Local Government and Urban Governance in Europe; Springer: Berlin/Heidelberg, Germany, 2017.

81. Schwab, C.; Bouckaert, G.; Kuhlmann, S. (Eds.) The Future of Local Government in Europe: Lessons from Research and Practice in 31 Countries; Nomos: Baden-Baden, Germany, 2017.

82. Bryson, J.M. What to do when stakeholders matter. Public Manag. Rev. 2004, 6, 21-53. [CrossRef] 